\title{
ANALISIS DETERMINAN VOLUME PERDAGANGAN SUKUK NEGARA RITEL SERI SR-007
}

\author{
Laily Farikhatun Ni'mah ${ }^{1}$, Ahmad Sidi Pratomo ${ }^{2}$ \\ Universitas Islam Negeri Maulana Malik Ibrahim Malang
}

$\triangle$ Corresponding Author:

Nama Penulis: Laily Farikhatun Ni'mah

E-mail: lailyfarikhatun17@gmail.com

\section{Abstract}

Trading volume of retail sukuk is the number of sheets of the State retail sukuk listed on the stock exchange. The country's retail sukuk issued to finance a deficit Budget of income and Expenditure of the State (STATE BUDGET) the purpose of this research is to examine and analyze the influence of internal factors and external factors against a trading volume of sukuk country retail series SR-007. This research uses descriptive kuantitaif approach. Researchers use the data monthly April 2015 period until March 2018. The variables used in this study is the price, the Yield to Maturity (YTM), exchange rates, For the results of Mudharabah Deposits, the BI rate, inflation and trading Volume of Sukuk Retail Series SR-007. The research analytical tool is Vector Error Correction models (VECM) using Eviews 9. The results of this research show that there is a shortterm relationship between variables that influence positive YTM against trading volume of sukuk retail series SR-007. In a long term relationship variables YTM, the exchange rate, the BI Rate, and inflation provide a positive influence against the trading volume of sukuk retail series SR-007. Variable YTM on long term negative effect against the trading volume of sukuk retail series SR-007.

Keywords: Trading Volume of Sukuk; Retail Sukuk; Internal Factors; External Factors

\section{Abstrak}

Volume perdagangan sukuk negara ritel merupakan jumlah lembar sukuk negara ritel yang diperdagangkan di bursa. Sukuk negara ritel diterbitkan untuk membiayai defisit Anggaran Pendapatan dan Belanja Negara (APBN). Tujuan dari penelitian ini adalah untuk menguji dan menganalisis pengaruh variabel mikroekonomi dan makroekonomi terhadap volume perdagangan sukuk negara ritel seri SR-007. Penelitian ini menggunakan pendekatan kuantitaif deskriptif. Peneliti menggunakan data bulanan periode April 2015 hingga Maret 2018. Variabel yang digunakan dalam penelitian ini adalah Harga, Yield to Maturity (YTM), Nilai Tukar, Bagi Hasil Deposito Mudharabah, BI rate, Inflasi dan Volume Perdagangan Sukuk Negara Ritel Seri SR-007. Alat analisis dalam penelitian ini yaitu Vector Error Correction Model (VECM) dengan menggunakan Eviews 9. Hasil penelitian ini menunjukkan bahwa terdapat hubungan jangka pendek antara variabel YTM yang berpengaruh positif terhadap volume perdagangan sukuk negara ritel seri SR-007. Pada hubungan jangka panjang variabel YTM, Nilai Tukar, BI Rate, dan Inflasi memberikan pengaruh yang positif terhadap volume perdagangan sukuk 
Laily F. Ni'mah: Analisis Determinan Volume Perdagangan Sukuk

negara ritel seri SR-007. Variabel YTM pada jangka panjang berpengaruh negatif terhadap volume perdagangan sukuk negara ritel seri SR-007

Kata kunci: Volume Perdagangan Sukuk; Sukuk Negara Ritel; Faktor Internal; Faktor Eksternal

\section{PENDAHULUAN}

Industri Keuangan Syariah di Indonesia mengalami pertumbuhan yang sangat pesat. Berdasarkan data statistik Otoritas Jasa Keuangan (OJK), pada tahun 2017 Indonesia berada pada posisi ke-9 dalam kategori total aset keuangan syariah terbesar dunia. Pada saat ini, Indonesia berada di posisi ke7 dunia dengan total aset keuangan syariah sebesar 81,84 milyar dollar. Pada akhir bulan Juni 2018, pasar modal syariah memberikan kontribusi paling besar bagi aset industri keuangan syariah. Pasar modal syariah memberikan kontribusi sebesar 55 persen. Hal ini menunjukkan bahwa pasar modal syariah mengalami pertumbuhan lebih besar dibandingkan lembaga keuangan syariah lainnya (Otoritas Jasa Keuangan, 2018). Defisit Anggaran Pendapatan dan Belanja Negara (APBN) tahun 2017 sebesar 2,57 persen (Kementerian Keuangan, 2017). Pemerintah akan menerbitkan Surat Berharga Negara dalam bentuk Surat Utang Negara (SUN) dan Surat Berharga Syariah Negara (SBSN) untuk menutupi defisit APBN (Manab, 2016).

Sukuk negara ritel SR-007 merupakan sukuk negara yang diterbitkan pada tanggal 11 Maret 2015 dan jatuh tempo pada tanggal 11 Maret 2018. Akad yang digunakan dalam SR-007 adalah ijarah asset to be leased. Imbal hasil yang diberikan kepada investor sebesar 8,25 persen per tahun. Sukuk negara ritel SR-007 diterbitkan melalui perusahaan penerbit SBSN diseluruh Indonesia (Suminto, 2015). Berikut ini merupakan 11 seri sukuk yang telah diterbitkan oleh Pemerintah (DJPPR Kementerian Keuangan, 2019):

Tabel 1. Sukuk Negara Ritel yang diterbitkan

\begin{tabular}{lccc}
\hline $\begin{array}{l}\text { Sukuk } \\
\text { Ritel }\end{array}$ & Negara & Keterangan & \\
\cline { 2 - 4 } & Volume (Triliun) & Kupon (Persen) & Tenor (Tahun) \\
\hline SR-001 & 5,565 & 12,00 & 3 \\
\hline SR-002 & 8,033 & 8,70 & 3 \\
\hline SR-003 & 7.341 & 8,15 & 3 \\
\hline SR-004 & 13,6 & 6,25 & 3 \\
\hline SR-005 & 14,968 & 6,00 & 3 \\
\hline SR-006 & 19,323 & 8,75 & 3 \\
\hline SR-007 & 21,965 & 8,25 & 3 \\
\hline SR-008 & 31,5 & 8,30 & 3 \\
\hline SR-009 & 31,5 & 6,90 & 3 \\
\hline SR-010 & 8,437 & 5,90 & 3 \\
\hline SR-011 & 21,11 & 8,05 & \\
\hline
\end{tabular}

Sumber: DJPPR Kementerian Keuangan, 2019 
Investor menggunakan volume perdagangan untuk melihat bagaimana perkembangan sukuk yang diperdagangkan di pasar sekunder. Investor melakukan investasi untuk mencari keuntungan. Berikut ini merupakan faktor-faktor utama yang menentukan tingkat investasi adalah: tingkat keuntungan yang diramalkan akan diperoleh, suku bunga, ramalan mengenai keadaan ekonomi di masa depan, kemajuan teknologi, tingkat pendapatan nasional dan perubahan-perubahannya serta keuntungan yang diperoleh perusahaan-perusahaan (Sukirno, 2011).

Berdasarkan latar belakang dan permasalahan diatas maka judul dalam penelitian ini adalah "Analisis Pengaruh Harga Sukuk Negara Ritel Seri SR007, Yield, Nilai Tukar, Tingkat Bagi Hasil Deposito Mudharabah, BI Rate, dan Inflasi terhadap Volume Perdagangan Sukuk Ritel Seri SR-007".

\section{KAJIAN PUSTAKA}

\section{Surat Berharga Syariah Negara}

Berdasarkan ketentuan Undang-Undang No.19 Tahun 2008 Surat Berharga Syariah Negara (SBSN) atau dapat disebut sukuk negara merupakan surat berharga negara yang diterbitkan berdasarkan prinsip syariah, sebagai bukti atas bagian penyertaan terhadap aset SBSN baik dalam mata uang rupiah maupun valuta asing. Dengan diterbitkannya UU Nomor 19 Tahun 2008 tentang Surat Berharga Syariah Negara, maka Pemerintah Republik Indonesia telah menerbitkan sukuk untuk menutupi defisit APBN (Muhammad, 2010).

\section{Investasi dan Pasar Modal Syariah}

Investasi merupakan pengeluaran penanam modal untuk memberi barang-barang dan perlengkapan-perlengkapan produksi untuk menambah kemampuan memproduksi suatu barang dan jasa (Sukirno, 2011). Menurut Fatwa Dewan Syariah Nasional No.40 tahun 2003 disebutkan bahwa pasar modal syariah adalah kegiatan yang berhubungan dengan perdagangan efek syariah perusahaan publik yang berkaitan dengan efek diterbitkannya, serta lembaga profesi yang akad, pengelolaan perusahaan, maupun cara penerbitannya memenuhi prinsip syariah.

\section{Volume Perdagangan Sukuk}

Teori permintaan menjelaskan bahwa makin rendah harga suatu barang maka makin banyak permintaan terhadap barang tersebut dan Sebaliknya (Sukirno, 2014). Tingkat permintaan sukuk negara ritel dapat dilihat dari jumlah (volume) sukuk yang terjual, yaitu sukuk yang diminta 
oleh investor pada pasar sekunder. Volume perdagangan dapat menggambarkan kekuatan antara minat jual dan beli pada transaksi pasar (Suharto, 2015 dalam Amaliyah, 2018).

\section{Harga Sukuk}

Harga adalah jumlah uang yang diperlukan sebagai penukar berbagai kombinasi produk dan jasa, oleh karena itu harga harus dihubungkan dengan bermacam-macam barang dan atau pelayaan yang akhirnya sama dengan suatu baik produk dan jasa (Laksana, 2008 dalam Rahman, 2016). Harga obligasi dinyatakan dalam bentuk persentase, yaitu persentase dari nilai nominal. Rumus perhitungan harga sukuk sebagai berikut:

$$
\mathrm{P}=\Sigma \frac{C}{(1+r) t}+\frac{M}{(1+r) n}
$$

Keterangan:

$$
\begin{aligned}
& \mathrm{P}=\text { Harga } \\
& \mathrm{n}=\text { Jumlah Periode } \\
& \mathrm{C}=\text { bayaran kupon } \\
& \mathrm{r}=\text { period kadar faedah }
\end{aligned}
$$

\section{Yield to Maturity (YTM)}

Yield adalah keuntungan yang diharapkan oleh investor atas investasi yang dilakukan yaitu berupa imbal hasil. Indikator yang digunakan untuk mengukur yield dalam penelitian ini adalah YTM (Yield to Maturity). Adapun untuk menghitung YTM (Wahid, 2010) dapat digunakan rumus sebagai berikut:

$$
\mathrm{YTM}=\mathrm{C}+\frac{\left[\frac{(\mathrm{R}-\mathrm{P})}{t}\right]}{\frac{(\mathrm{R}+\mathrm{p})}{2 \times 100}}
$$

Keterangan:

$$
\begin{aligned}
& \mathrm{C}=\text { Coupon } \\
& \mathrm{R}=\text { Redemtion } \text { price } \\
& \mathrm{P}=\text { Current } \text { Price of the sukuk } \\
& \mathrm{t}=\text { Remaining time until maturity }
\end{aligned}
$$

\section{Nilai Tukar}

Nilai tukar menurut Sukirno (2011) dapat diartikan sebagai jumlah uang domestik yang dibutuhkan. Dalam penelitian ini nilai tukar yang digunakan adalah nilai tukar tengah terhadap dollar Amerika. Menurut 
Ekananda (2014) untuk menghitung nilai kurs tengah dapat digunakan rumus sebagai berikut:

$$
\text { Kurs tengah }=\frac{\mathrm{Kb}+\mathrm{Kj}}{2}
$$

\section{Tingkat Bagi Hasil Deposito Mudharabah}

Deposito Mudharabah adalah simpanan dana dengan skema pemilik dana (shahibul maal) memercayakan dananya kepada bank syariah (mudharib) dengan hasil yang diperoleh dibagi antara pemilik dana dengan bank berdasarkan nisbah yang telah disepakati (Yaya, 2014). Dalam penelitian ini menggunakan tingkat bagi hasil deposito mudharabah di bank syariah dengan jangka waktu satu bulan.

\section{BI Rate}

BI Rate atau suku bunga merupakan sebuah harga yang menghubungkan masa kini dengan masa depan, tingkat suku bunga juga ditentukan oleh interaksi transaksi antara permintaan dan penawaran (Amaliyah, 2018).

\section{Inflasi}

Inflasi menurut Sukirno (2011) adalah kenaikan harga yang berlaku dalam suatu perekonomian. Indikator yang digunakan untuk mengukur inflasi adalah IHK (indeks harga konsumen). Dalam menghitung inflasi (Bella, 2018 ) bisa digunakan rumus sebagai berikut:

$$
I H K=\frac{\text { tingkat harga }_{t}-\text { tingkat harga }_{t-1}}{\text { tingkat harga } a_{t-1}} \times 100 \%
$$

\section{METODE PENELITIAN}

Berdasakan jenis data, penelitian ini disebut penelitian kuantitatif dengan pendekatan deskriptif. Penelitian dilakukan melalui web resmi lembaga pendidikan dan pelatihan pasar modal The Indonesia Capital Market Institute (TICMI) dengan objek penelitiannya yaitu sukuk negara ritel SR-007 pada periode 2015-2018. Data volume perdagangan sukuk negara ritel, harga sukuk negara ritel dan yield diperoleh dari The Indonesia Capital Market Institute (TICMI). Data tingkat bagi hasil deposito mudharabah diperoleh dari web resmi OJK (www.ojk.go.id). Data nilai tukar kurs, BI rate dan inflasi diperoleh dari (www.bi.go.id).

Analisis data yang digunakan dalam penelitian ini adalah menggunakan analisis model VAR (vector autoregressive) dan VECM (vector error corection model) yang diolah dengan program Eviews 9. Definisi operasional variabel yang digunakan dalam penelitian ini ditunjukkan pada Tabel 2. berikut ini: 
Tabel 2. Definisi Operasional Variabel

\begin{tabular}{|c|c|c|c|}
\hline $\begin{array}{c}\text { Definisi } \\
\text { Operasional } \\
\text { Variabel }\end{array}$ & Variabel & Rumus & Skala \\
\hline & $\begin{array}{l}\text { Harga } \\
\text { (HRG) }\end{array}$ & $\mathrm{P}=\Sigma \frac{C}{(1+r) t}+\frac{M}{(1+r) n}$ & Persen \\
\hline & $\begin{array}{l}\text { Yield } \\
\text { (YTM) }\end{array}$ & $\mathrm{YTM}=\mathrm{C}+\frac{\left[\frac{(\mathrm{R}-\mathrm{P})}{t}\right]}{\frac{(\mathrm{R}+\mathrm{p})}{2 \times 100}}$ & Persen \\
\hline & $\begin{array}{l}\text { Nilai Tukar } \\
\text { (NT) }\end{array}$ & Kurs tengah $=\frac{\mathrm{Kb}+\mathrm{Kj}}{2}$ & Rupiah \\
\hline \multirow[t]{2}{*}{$\begin{array}{c}\text { Variabel } \\
\text { Independen }\end{array}$} & $\begin{array}{l}\text { Tingkat Bagi } \\
\text { Hasil Deposito } \\
\text { Mudharabah } \\
\text { (BDM) } \\
\text { Bi Rate } \\
\text { (BR) }\end{array}$ & $\begin{array}{l}\text { Tingkat Bagi Hasil Deposito } \\
\text { Mudharabah di bank syariah } \\
\text { dengan jangka waktu satu } \\
\text { bulan } \\
\text { Tingkat suku bunga bulanan } \\
\text { yang ditetapkan oleh Bank } \\
\text { Indonesia }\end{array}$ & $\begin{array}{l}\text { Persen } \\
\text { Persen }\end{array}$ \\
\hline & $\begin{array}{l}\text { Inflasi } \\
\text { (INF) }\end{array}$ & $\begin{array}{l}\text { IHK }= \\
\frac{\text { tingkat hargat }}{\text { tingkat harga } a_{t-1}} \\
\quad \times 100 \%\end{array}$ & Persen \\
\hline $\begin{array}{l}\text { Variabel } \\
\text { Dependen }\end{array}$ & $\begin{array}{l}\text { Volume } \\
\text { Perdagangan } \\
\text { (VOL) }\end{array}$ & $\begin{array}{l}\text { Jumlah sukuk SR-007 yang } \\
\text { diperdagangkan di bursa }\end{array}$ & Rupiah \\
\hline
\end{tabular}

\section{Sumber: Data diolah peneliti (2018)}

\section{HASIL DAN PEMBAHASAN}

\section{A. Gambaran Umum Obyek Penelitian}

Sukuk negara ritel seri SR-007 adalah seri ke-7 dari sukuk ritel yang diterbitkan oleh Pemerintah dengan tenor 3 tahun mulai 11 Maret 2015 dan jatuh tempo pada 11 Maret 2018 dengan jangka waktu penawaran selama 2 pekan sejak 23 Februari 2015 dan ditutup pada tanggal 6 Maret 2015 dan diterbitkan khusus untuk investor individu Warga Negara Indonesia (WNI). Nilai nominal per unit adalah Rp 1.000.000, dengan minimal pembelian sebesar Rp. 5.000.000 dan kelipatannya dengan maksimal pembelian Rp. 5.000.000.000. Imbalan yang diberikan oleh sukuk negara ritel SR-007 adalah sebesar $8.25 \%$ per tahun. Pembelian sukuk dapat dilakukan melalui agen penjual sukuk yang telah ditetapkan oleh Menteri Keuangan melalui Direktrorat Jenderal Pengelolaan Utang (DJPU). Agen Penjual sukuk terdiri dari perusahaan sekuritas dan perbankan.

\section{B. Uji Stasioneritas}

Uji Stasioneritas dilakukan dengan metode Augmented Dicky Fuller (ADF). Berdasarkan hasil uji stasioneritas dapat diketahui bahwa hanya 
variabel VOL dan YTM berdasarkan uji Augmented Dickey-Fuller dengan probabilitas dibawah 0,05 sehingga dapat diinyatakan telah stasioner pada tingkat level. Sementara variabel lainnya yaitu HRG, NT, BDM, BR dan INF diinyatakan telah stasioner pada tingkat fist different.

\section{Penentuan Lag Optimum}

Lag optimum adalah jumlah lag yang diperkirakan untuk menghindari permasalahan autokorelasi maupun heteroskedastisitas.

Tabel 3. Hasil Lag Optimum

\begin{tabular}{cccccc}
\hline Lag & \multicolumn{5}{c}{ Kriteria } \\
\cline { 2 - 6 } & LR & FPE & AIC & SC & HQ \\
\hline 0 & NA & $5.85 \mathrm{e}-05$ & 10.11823 & 10.43248 & 10.22540 \\
\hline 1 & 220.9236 & $2.27 \mathrm{e}-07$ & 4.503525 & $7.017530^{*}$ & $5.360873^{*}$ \\
\hline 2 & $66.98139^{*}$ & $1.77 \mathrm{e}-07^{*}$ & $3.860542^{*}$ & 8.574302 & 5.468069 \\
\hline
\end{tabular}

Sumber: Output Eviews 9 diolah, 2019

Berdasarkan hasil pada Tabel 3. diketahui bahwa nilai AIC terkecil sebesar 3.860542* pada lag 2. Dengan demikian lag optimum yang dihasilkan adalah 2 lag. Penetuan panjang lag juga digunakan untuk mengetahui stabilitas sistem VAR. Sistem VAR dikatakan stabil jika seluruh roots-nya memiliki modulus yang lebih kecil atau mendekati satu. Berdasarkan uji stabilitas lag juga diketahui bahwa seluruh roots-nya memiliki modulus yang lebih kecil atau mendekati satu.

\section{Uji Kointegrasi}

Uji kointegrasi dengan menggunakan metode uji johansen, dimana nilai trace statistic 0 (none) sebesar $228.3578>$ critical value at 5\% yaitu 125.6154. Dengan demikian dapat dinyatakan terdapat 2 kointegrasi yang digunakan dalam penelitian ini. Adanya kointegrasi ini dapat diartikan bahwa terdapat hubungan jangka panjang antara variable.

\section{E. Estimasi VECM}

Adanya pengaruh jangka pendek atau jangka panjang ini dapat dilihat dengan t-statistik yang dimiliki lebih besar dari 1.98 (Ekananda, 2014). Berdasarkan Tabel 4. diketahui bahwa untuk persamaan volume dalam jangka pendek, terdapat satu variabel yang menunjukkan pengaruh signifikan, yaitu variabel YTM pada 1 periode sebelumnya. Koefisien YTM pada 1 periode sebelumnya sebesar -2.918343 , sehingga dapat dinyatakan bahwa meningkatnya volume sebesar $1 \%$ pada 1 periode sebelumnya akan menurunkan volume pada periode saat ini sebesar $2.918343 \%$. 
Laily F. Ni'mah: Analisis Determinan Volume Perdagangan Sukuk

Tabel 4. Hasil Estimasi Jangka Pendek

\begin{tabular}{ccc}
\hline & Jangka Pendek & \\
\hline Variabel & Koefisien & t statistik \\
\hline D(HRG(-1)) & -2.807288 & -1.56794 \\
\hline $\mathrm{D}($ HRG(-2)) & -0.132681 & -0.08543 \\
\hline $\mathrm{D}($ YTM(-1)) & -2.918343 & --2.75879 \\
\hline $\mathrm{D}($ YTM(2)) & 1.029757 & 0.82920 \\
\hline $\mathrm{D}(\mathrm{NT}(-1))$ & 81.90204 & 0.91271 \\
\hline $\mathrm{D}(\mathrm{NT}(-2))$ & -77.33077 & -1.13864 \\
\hline $\mathrm{D}(\mathrm{BDM}(-1))$ & -12.37763 & -1.77183 \\
\hline $\mathrm{D}(\mathrm{BDM}(2))$ & -2.54443 & -0.39655 \\
\hline $\mathrm{D}(\mathrm{BR}(-1))$ & -5.840744 & -1.55483 \\
\hline $\mathrm{D}(\mathrm{BR}(-2))$ & -0.058293 & -0.01433 \\
\hline $\mathrm{D}(\mathrm{INF}(-1))$ & 2.635962 & 1.45424 \\
\hline $\mathrm{D}(\mathrm{INF}(2))$ & -0.694608 & -0.37378 \\
\hline Adj. R-squared & 0.508413 &
\end{tabular}

Sumber: Output Eviews 9 diolah, 2019

Secara simultan terdapat pengaruh yang signifikan antara volume, harga, YTM, nilai tukar, bdm, BI rate dan inflasi pada 1 hingga 2 periode sebelumnya terhadap volume pada periode saat ini. Nilai adj. $\mathrm{R}^{2}$ sebesar 0.508413 dengan demikian dapat dikatakan bahwa kontribusi volume, harga, YTM, nilai tukar, bdm, BI rate dan inflasi pada 1 hingga 2 periode sebelumnya terhadap volume pada periode saat ini sebesar 50.8413\%.

\section{F. Analisis Impulse Respon Function (IRF)}

Analisis IRF memberikan informasi tentang indikator volume yaitu kecepatan atau berapa waktu lag yang dibutuhkan untuk merespon perubahan dan kekuatan variabel lain. Hasil IRF pada Tabel 5. diketahui bahwa volume memberikan respon yang cukup berfluktuatif terhadap perubahan volume, harga, yield, nilai tukar, tingkat bagi hasil deposito mudharabah, BI Rate, dan inflasi.

Tabel 5. Impulse Response Function (IRF)

\begin{tabular}{|c|c|c|c|c|c|c|c|}
\hline $\begin{array}{l}\text { Response } \\
\text { of VOL: } \\
\text { Period }\end{array}$ & VOL & HRG & YTM & NT & BDM & BR & INF \\
\hline 1 & .359480 & 0.000000 & 0.000000 & 0.000000 & 0.000000 & 0.000000 & 0.000000 \\
\hline 2 & 0.504399 & -0.185021 & -1.788489 & 1.187925 & -2.001417 & -0.544 & 0.292397 \\
\hline 3 & 1.417635 & 0.610820 & -0.316086 & 0.965411 & -0.018052 & -0.152 & 0.212707 \\
\hline 4 & 0.716745 & 0.372918 & 0.031497 & -0.121590 & -0.916993 & -0.181 & -0.231785 \\
\hline 5 & 0.869557 & 0.949043 & -0.203135 & -0.185721 & -0.445467 & -0.032337 & -0.035930 \\
\hline 6 & 1.073324 & 0.818142 & -1.116762 & 0.17 & -0.498408 & -0.03 & 0.040474 \\
\hline 7 & 1.334757 & 0.401014 & -0.671902 & 0.362495 & -1.374633 & 0.000561 & 0.042244 \\
\hline 8 & 1.219111 & 0.435413 & 0.164071 & -0.106942 & -0.537087 & 0.114698 & -0.034114 \\
\hline 9 & 1.520779 & 0.727577 & -0.256722 & -0.6 & 784 & 0.218979 & -0.171571 \\
\hline 10 & 1.404934 & 0.536115 & -1.084281 & 0.090633 & -0.937264 & 0.122840 & 0.068051 \\
\hline
\end{tabular}

Sumber: Output Eviews 9 diolah, 2019 
Laily F. Ni'mah: Analisis Determinan Volume Perdagangan Sukuk

Respon volume terhadap perubahan volume selalu positif, sementara respon volume terhadap variabel lainnya adalah positif dan negatif.

\section{G. Analisis Variance Decomposition}

Informasi yang disampaikan oleh FEVD adalah mengenai proporsi dari pergerakan atau pengaruh shock pada sebuah variabel terhadap variabel lainnya pada periode saat ini dan yang akan datang (Ajija, 2011).

Tabel 6. Hasil Analisis Variance Decomposition

\begin{tabular}{ccccccccc}
\hline Period & S.E. & VOL & HRG & YTM & NT & BDM & BR & INF \\
\hline 1 & 3.359480 & 100.0000 & 0.000000 & 0.000000 & 0.000000 & 0.000000 & 0.000000 & 0.000000 \\
\hline 2 & 4.535606 & 56.09895 & 0.166407 & 15.54898 & 6.859737 & 19.47172 & 1.438595 & 0.415601 \\
\hline 3 & 4.904633 & 56.32914 & 1.693313 & 13.71252 & 9.740773 & 16.65319 & 1.327570 & 0.543498 \\
\hline 4 & 5.064731 & 54.82696 & 2.130095 & 12.86317 & 9.192322 & 18.89508 & 1.373255 & 0.719120 \\
\hline 5 & 5.252127 & 53.72539 & 5.245942 & 12.11122 & 8.673098 & 18.29016 & 1.280798 & 0.673398 \\
\hline 6 & 5.561951 & 51.63061 & 6.841508 & 14.83101 & 7.833416 & 17.11223 & 1.145459 & 0.605761 \\
\hline 7 & 5.945750 & 50.21976 & 6.441663 & 14.25514 & 7.226458 & 20.31950 & 1.002354 & 0.535129 \\
\hline 8 & 6.113011 & 51.48638 & 6.601313 & 13.55777 & 6.867021 & 19.99470 & 0.983458 & 0.509360 \\
\hline 9 & 6.392747 & 52.73828 & 7.331567 & 12.55847 & 7.248329 & 18.56896 & 1.016607 & 0.537788 \\
\hline 10 & 6.723878 & 52.03766 & 7.262968 & 13.95241 & 6.570159 & 18.72812 & 0.952319 & 0.496366 \\
\hline
\end{tabular}

Sumber: Output Eviews 9 diolah, 2019

Dari Tabel 6. diketahui bahwa kontribusi terbesar yang mempengaruhi volume bersumber dari dirinya sendiri.

\section{Pengaruh Harga Sukuk terhadap Volume Perdagangan Sukuk SR-007}

Hasil penelitian menunjukkan bahwa tidak terdapat pengaruh yang signifikan baik dalam jangka pendek dan jangka panjang antara variabel harga terdapat volume sukuk SR-007. Hal ini tidak sesuai dengan hukum permintaan yang menyatakan semakin tinggi harga suatu barang, maka semakin sedikit permintaan terhadap barang tersebut (Sukirno, 2014). Hal ini disebabkan sukuk negara ritel seri SR-007 tidak mempunyai risiko gagal bayar dan dijamin oleh Pemerintah (Suminto, 2015).

\section{Pengaruh YTM terhadap Volume Perdagangan Sukuk SR-007}

Pada umumnya investor akan membeli sukuk jika tingkat imbal hasil yang diberikan lebih tinggi karena dianggap dapat memberikan keuntungan yang menjanjikan (Yusiarmayanti, 2017). Hasil penelitian menunjukkan bahwa terdapat pengaruh yang signifikan baik dalam jangka pendek dan jangka panjang antara variabel YTM terhadap volume sukuk SR-007. Semakin likuid obligasi maka harga obligasi menjadi cenderung stabil dan meningkat. 
Harga obligasi yang terus meningkat menyebabkan yield obligasi menurun dikarenakan tingkat risikonya lebih rendah (Krisnilasari, 2007).

\section{Pengaruh Nilai Tukar terhadap Volume Perdagangan Sukuk SR-007}

Kurniati (2007) menyatakan bahwa motif dari investor asing menanamkan modalnya di Asia dan Indonesia yaitu dikarenakan investor menaruh perhatian besar terhadap potensi pasar maupun stabilitas nilai tukar yang mencerminkan stabilitas finansial. Jika nilai tukar rupiah menguat, maka investor domestik ataupun investasi asing akan tertarik untuk berinvestasi khususnya investasi terhadap sukuk (Putri, 2018). Berdasarkan hasil penelitian yang dilakukan oleh Bhattacharyay (2013) dan Smaoui (2016) diketahui bahwa nilai tukar berpengaruh negatif terhadap pertumbuhan sukuk korporasi.

Hasil penelitian menunjukkan bahwa dalam jangka panjang terdapat pengaruh yang signifikan dan positif antara variabel nilai tukar terhadap volume sukuk SR-007. Hal itu menunjukkan bahwa negara tersebut memiliki kondisi ekonomi yang relatif baik, sehingga dapat mendorong investor untuk berinvestasi pada sukuk.

\section{Pengaruh Tingkat Bagi Hasil Deposito Mudharabah terhadap Volume Perdagangan Sukuk SR-007}

Tingkat imbal hasil yang tinggi pada deposito ini akan meningkatkan keinginan masyarakat untuk berinvestasi pada investasi tersebut sehingga dapat menurunkan keinginan masyarakat dalam berinvestasi pada sukuk (Agustiatno, 2013 dalam Ardiansyah 2016). Berdasarkan hasil uji estmasi VECM, diketahui bahwa dalam jangka panjang variabel bagi hasil deposito mudharabah memiliki pengaruh yang negatif dan signifikan terhadap volume perdagangan sukuk negara ritel seri SR-007. Hal ini disebabkan karena semakin tinggi jumlah dana yang didepositkan maka semakin tinggi pula tingkat bagi hasil yang diterima. Oleh karena itu dalam jangka panjang kenaikan pada bagi hasil deposito mudharabah akan menurunkan volume perdagangan sukuk.

\section{Pengaruh BI rate terhadap Volume Perdagangan Sukuk SR-007}

Suku bunga juga merupakan sebuah harga yang menghubungkan masa kini dengan masa depan, tingkat suku bunga juga ditentukan oleh interaksi transaksi antara permintaan dan penawaran (Kewal, 2012 dalam Amaliyah, 2018). Berdasarkan hasil uji estimasi VECM, Dalam jangka panjang BI rate memiliki pengaruh positif dan signifikan terhadap volume perdagangan sukuk negara ritel SR-007. Hal ini disebabkan pada awal waktu pengamatan, 
suku bunga atau BI rate cenderung stabil pada angka $7.5 \%$. Kondisi ini mengindikasikan bahwa perekonomian Indonesia cenderung stabil. Hal ini dapat meningkatkan volume perdagangan sukuk.

\section{Pengaruh Inflasi terhadap Volume Perdagangan Sukuk SR-007}

Menurut Sukirno (2011) inflasi yang tinggi tidak akan menggalakkan perkembangan ekonomi. Berdasarkan hasil uji estimasi VECM, dalam jangka panjang inflasi memiliki pengaruh positif dan signifikan terhadap volume perdagangan sukuk negara ritel SR-007. Hal ini dikarenakan selama tahun pengamatan inflasi yang terjadi setiap bulan masih bisa dikendalikan dengan nilai inflasi yang tidak melebihi 10\%. Dengan tingkat inflasi yang masih bisa dikendalikan dan stabil, maka kondisi perekonomian negara juga stabil, sehingga investor akan tertarik untuk berinvestasi dalam sukuk, hal ini akan menyebabkan volume perdagangan sukuk akan meningkat.

\section{KESIMPULAN}

Dari hasil penelitian tersebut, dapat ditarik beberapa kesimpulan sebagai berikut:

1. Variabel Harga sukuk memiliki pengaruh yang tidak signifikan terhadap volume perdagangan sukuk negara ritel SR-007 dalam jangka pendek dan jangka panjang. Hal ini disebabkan sukuk negara ritel seri SR-007 tidak mempunyai risiko gagal bayar dan dijamin oleh Pemerintah.

2. Variabel YTM (Yield to Maturity) memiliki pengaruh negatif dan signifikan pada jangka pendek, namun memiliki pengaruh positif dan signifikan dalam jangka panjang terhadap volume perdagangan sukuk negara ritel SR-007. Hal ini disebabkan semakin likuid obligasi maka harga obligasi menjadi cenderung stabil dan meningkat. Harga obligasi yang terus meningkat menyebabkan yield obligasi menurun dikarenakan tingkat risikonya lebih rendah.

3. Variabel Nilai tukar rupiah terhadap dollar Amerika Serikat memiliki pengaruh yang tidak signifikan pada jangka pendek dan memiliki pengaruh postif signifikan dalam jangka panjang terhadap volume perdagangan sukuk negara ritel SR-007. Nilai tukar yang stabil merupakan indikasi dari pertumbuhan ekonomi. Kestabilan nilai tukar pada akhirnya akan berpengaruh terhadap peningkatan volume perdagangan sukuk.

4. Variabel tingkat bagi hasil deposito mudharabah di Bank Syariah memiliki pengaruh yang tidak signifikan pada jangka pendek, namun memiliki pengaruh negatif signifikan dalam jangka panjang terhadap volume perdagangan sukuk negara ritel SR-007. Semakin tinggi dana 
yang didepositkan maka semakin tinggi pula tingkat imbal hasil yang diterima. Tingkat imbal hasil deposito mudharabah yang tinggi pada akhirnya akan berpengaruh pada penurunan volume perdagangan sukuk.

5. Variabel BI rate memiliki pengaruh yang tidak signifikan pada jangka pendek dan memiliki pengaruh positif signifikan pada jangka panjang terhadap volume perdagangan sukuk negara ritel SR-007. Tingkat suku bunga yang stabil merupakan indikasi pertumbuhan ekonomi. Hal ini akan berpengaruh terhadap peningkatan volume perdagangan sukuk.

6. Variabel inflasi memiliki pengaruh yang tidak signifikan pada jangka pendek dan memiliki pengaruh positif signifikan pada jangka panjang terhadap volume perdagangan sukuk negara ritel SR-007. Tingkat inflasi yang masih bisa dikendalikan dan stabil dapat diartikan bahwa perekonomian juga stabil. Hal ini akan mendorong investor untuk berinvestasi pada sukuk, sehingga volume perdagangan akan meningkat.

Dari hasil penelitian di atas, peneliti memberikan saran bagi peneliti selanjutnya bisa menambah variabel lain diluar variabel yang sudah diteliti misalnya : SBIS, PDB, suku bunga deposito bank konvensional dan lain-lain.

\section{DAFTAR PUSTAKA}

Ajija, Shochrul R, dkk. (2011). Cara Cerdas Menguasai Eviews. Jakarta: Salemba Empat.

Amali, Qisthi. (2018). Analisis Faktor-faktor yang Mempengaruhi Volume Perdagangan Sukuk Negara Ritel SR-006 di Indonesia, skripsi (tidak dipublikasikan). Fakultas Ekonomi dan Bisnis UIN Syarif Hidayatullah, Jakarta.

Ardiansyah, Ivan. (2016). Analisis Pengaruh Variabel Makroekonomi Terhadap Pertumbuhan Sukuk Korporasi Di Indonesia, skripsi (tidak dipublikasikan). Fakultas Ekonomi dan Manajemen Institut Pertanian Bogor, Bogor.

Ekananda, Mahyus. (2014). Analisis Data Time Series Untuk Penelitian Ekonomi, Manajemen dan Akuntansi. Jakarta: Mitra Wacana Media.

Bella, Firsty Izzata. (2018). Analisis Variabel Makroekonomi dan Yield Sukuk Ritel Terhadap Volume Penerbitan Sukuk Ritel Negara Seri 006 di Indonesia 2014-2017. skripsi (tidak dipublikasikan). Fakultas Ekonomi dan Bisnis UIN Syarif Hidayatullah, Jakarta.

Bhattacharyay, B.N. (2013). Determinants of Bond Market Development in Asia. Journal of Asian Economics, 124-137.

Krisnilasari, M. (2007). Analisis Pengaruh Likuiditas Obligasi, Coupun dan Jangka Waktu Jatuh Tempo Obligasi Terhadap Perubahan Harga Obligasi 
di Bursa Efek Indonesia. Tesis (tidak dipublikasikan). Program Magister Manajemen. Universitas Diponegoro.

Kurniati, et al. (2007). Determinan FDI (Faktor-Faktor Yang Menentukan Investasi Asing Langsung). Bank Indonesia, Agustus, Working Paper 06.

Manab, Abdul dan Agus Eko Sujianto. (2016). Pengaruh Stabilitas Ekonomi Makro Terhadap Penerbitan Sukuk Negara di Indonesia, Malaysia, dan Brunei Darussalam. Tulungagung: Cahaya Abadi.

Muhammad, Abdul Qoyyum dan Ahmad Sidi Pratomo. (2010). Akselerasi Perbankan Syariah Pasca UU Nomor 19 Tahun 2008 Tentang Surat Berharga Syariah Negara (Pengaruh Terhadap Portofolio Investasi dan Kebijakan Struktur Modal Syariah). Jurnal Asy-Syirah, Volume 44, 384:404.

Otoritas Jasa Keuangan. (2018). Snapshot Perbankan Syariah Juni 2018.

Diperoleh tanggal 17 Desember 2018 dari

https://www.ojk.go.id/id/kanal/syariah/berita-dan

kegiatan/publikasi/Documents/Pages/Snapshot-Perbankan-Syariah-

Indonesia-Juni-2018/Snapshot\%20Juni\%202018\%20(final).pdf

Rahman, Faizul dkk. (2016). Pengaruh Harga Sukuk Negara Ritel Seri SR-005, Tingkat Inflasi dan Bi Rate Terhadap Tingkat Permintaan Sukuk Negara Ritel Seri SR-005. Jurnal Manajemen, 8 (1), 19-29.

Putri Cipto, Rahajeng Cahyaning. (2013). Pengaruh Faktor Domestik dan Asing Terhadap Permintaan Surat Berharga Syariah Negara di Indonesia. Jurnal Akuntansi Manajemen Madani, 2 (1), 1-20.

Smaoui, H. Khawaja. M. (2016). The Determinants of Sukuk Market Development, Journal Emerging Markets Finance and Trade, 1-37.

Sukirno, Sadono. (2011). Makroekonomi Teori Pengantar (Edisi 1, Cet. Ke-20). Jakarta: Rajawali Pers.

Sukirno, Sadono. (2014). Mikroekonomi Teori Pengantar (Edisi 3, Cet. Ke-29). Jakarta: Rajawali Pers.

Suminto. (2015). Prospektus SR-007. (pp.1-29). Jakarta. Diperoleh tanggal 24 September 2018 dari http://islamicmarket.com/publications/sukuknegara-ritel-seri-sr-007-8-25-11-mar-2018-memorandum-informasi).

Wahid, Nazaruddin Abdul. (2010). Sukuk: Memahami \& Membedah Obligasi pada Perbankan Syariah. Yogyakarta: Ar-Ruz Media.

Yaya, Rizal, Aji Erlangga Martawireja, dan Ahim Abdurahim. (2014). Akuntansi Perbankan Syariah Teori dan Praktik Kontemporer Berdasarkan PAPSI 2013. Jakarta: Salemba Empat.

Yusiarmayanti, Rita. (2017). Faktor-Faktor yang Memengaruhi Volume Perdagangan Sukuk Negara Ritel SR-005 di Indonesia 2013-2016, skripsi. Fakultas Ekonomi dan Manajemen Institut Pertanian Bogor, Bogor.

http://www.djppr.kemenkeu.go.id diakses 25 Maret 2019, dari http://www.djppr.kemenkeu.go.id/page/load/1199 